\title{
EFFECT OF IRRIGATION AND ANTITRANSPIRANT TREATMENTS ON GROWTH, YIELD AND CHEMICAL CONSTITUENTS OF MARJORAM PLANTS (Majorana hortensis MOENCH)
}

(Received: 8. 4.2010)

\author{
By \\ T.A.M. Abou Dahab, I.M.A. Harridy * and B.A.B Mansour * \\ Ornamental Horticulture Department, Faculty of Agriculture, Cairo University, Giza, Egypt. \\ * Medicinal and Aromatic Plants Department, Horticulture Research Institute, Agricultural Research \\ Center,Giza, Egypt.
}

\begin{abstract}
This work was carried out during 2005/2006 and 2006/2007 seasons, at the Experimental Nursery of Ornamental Horticulture Department, Faculty of Agriculture, Cairo University. The investigation aimed to study the effects of irrigation at 25,50 and $75 \%$ of available soil moisture depletion (ASMD) combined with antitranspirant agents: active dry yeast (ADY) at 6 or $8 \mathrm{~g} / \mathrm{l}$ as bio-antitranspirant, sodium salicylate (S.S.) at 10 or $20 \mathrm{ppm}$ and magnesium carbonate $\left(\mathrm{MgCO}_{3}\right)$ at 15 or $30 \mathrm{ppm}$ as chemicalantitranspirants beside the control (0.0) in order to regulate water irrigation and study their effect on vegetative growth and volatile oil characteristics of marjoram plants (Majorana hortensis, Moench). The obtained results are summarized as follows: in all cuts in the two seasons, the plants received ADY at 6 or $8 \mathrm{~g} / \mathrm{l}$ were significantly taller than the plants treated with (S.S. and $\mathrm{MgCO}_{3}$ ) or the control. The same trend was observed on the branching of marjoram plants. The lowest value was when the plants were treated with $\mathrm{MgCO}_{3}$ at $30 \mathrm{ppm}$ in most cases. The percentage of volatile oil in all treatments decreased except the treatment of $\mathrm{MgCO}_{3}$ at the rate of $30 \mathrm{ppm}$ in the first season, and the treatment of S.S. at the rate of 10 $\mathrm{ppm}$ in the second cut of the second season. The highest volatile oil per plant and per feddan through the two seasons was achieved when the plants were sprayed with ADY at 6 or $8 \mathrm{~g} / \mathrm{l}$ combined with irrigation at 25\% ASMD. On the other hand, GLC analysis of the oil in the second cut of the first season showed that Terpinene-4-ol, Linalyl acetate and $\alpha$-Terpineol were the main components in the volatile oil using the irrigation treatment at the rate of 25 or $75 \%$ ASMD.
\end{abstract}

Key words: active dry yeast, antitranspirants, ASMD , Essential oil, Majorana hortensis Moench

\section{INTRODUCTION}

Medicinal and aromatic plants have a major role in agriculture industry. They are the main source of safety drugs and raw substances used in manufacturing pharmaceuticals (Mahfouz, 2003). Marjoram plants (Majorana hortensis Moench) is one of the most important medicinal plants cultivated in Egypt. A volatile oil produced by this plant is antispasmodic, digestive, bitter tonic, expectorant diuretic, antidiabetic, antimicrobial, antioxidant, antihysterial, antiasthmatic. Fresh marjoram is used as a component to fine herbs or alone to flavor foods, sausages or vegetables (Yadava and Khore, 1995). Nowadays, water is considered as the main factor in Egyptian cultivation, since the amount of water is limited, and the cultivated areas increased as a result of land reclamation.

The large amount of the water consumed by the plant is lost through the leaf stomata. Many investigators studied the possibility of retarding the plant transpiration via the foliar application of chemical substances that act in closing the leaf stomata. Therefore, antitranspirant agents can be used to reduce the transpiration rate, without toxicity by forming a film on the leaf surface to prevent moisture loss especially during drought periods (Nasroui, 1993).

Sodium salicylate (S.S.), magnesium carbonate $\left(\mathrm{MgCO}_{3}\right)$ and active dry yeast (ADY) can be used in reducing the harmful effect of stress, to improve the, yield and to produce high quantity of active substances (Ahmed et al., 2001). El-Bably and Awad (2007) studied the effect of irrigation at 45, 60 and $75 \%$ of available soil moisture deficit (ASMD), and found that the best results when canola plants were irrigated at $45 \%$ ASMD.

This study was conducted to investigate the effect of irrigation at different available soil moisture depletion (ASMD) rates as well as antitranspirants agents: active dry yeast (ADY) as bio-antitranspirant, sodium salicylate (S.S.) and 
magnesium carbonate $\left(\mathrm{MgCO}_{3}\right)$ both as chemicalantitranspirants on the vegetative growth and volatile oil characteristics of marjoram plants (Majorana hortensis).

\section{MATERIALS AND METHODS}

This study was carried out at the Experimental Nursery of Ornamental Horticulture Department, Fac. Agric., Cairo Univ., during 2005/2006 and $2006 / 2007$ seasons. The aim of this study was to investigate the effect of irrigation at different available soil moisture depletion (ASMD), bio and chemical antitranspirants (AT's) and their interactions on the vegetative growth, yield and chemical constituents of marjoram plants (Majorana hortensis Moench).

\subsection{Experimental procedures}

Marjoram seedlings $(12-15 \mathrm{~cm}$ in height, with 10-12 leaves) were obtained from local nursery (Al-Ayaat area, south Giza) and transplanted in the soil on $15^{\text {th }}$ February and on the $31^{\text {st }}$ of January in the first and second seasons, respectively. The soil of the experiment was prepared and divided into plots $\left(2 \times 2 \mathrm{~m}^{2}\right.$ each $)$ containing 3 rows in each plot, 24 plants were planted in each plot. The physical and chemical characteristic of the soil are shown in Table (a).

\subsection{Treatments}

The following irrigation and antitranspirant treatments were carried out after 30 days from transplanting:

2.2.1. Irrigation was done at 25,50 and $75 \%$ of available soil moisture depletion (ASMD), the soil moisture content was determined before irrigation. The chemical analyses of the water used in irrigation are shown in Table (b) according to Chapman and Pratt (1961).

2.2.2. Antitranspirants: The plants were sprayed with different antitranspirants 3 times at monthly intervals. Active dry yeast (ADY) was used as bioantitranspirants at 6 or $8 \mathrm{~g} / \mathrm{l}$, while both sodium salicylate (S.S.) at 10 or $20 \mathrm{ppm}$ and magnesium carbonate $\left(\mathrm{MgCO}_{3}\right)$ at 15 or $30 \mathrm{ppm}$ were used as chemical antitranspirants.

The plants were harvested twice, the first cut was at the end of May, and the second one at $15^{\text {th }}$ July in both seasons.

\subsection{Experiment layout}

The experiment layout was designed in split plots, with 21 treatments, (three replicates for each treatment), irrigation treatments occupied the main plot, while antitranspirant treatments were arranged in subplots.

The statistical analysis was conducted according to Snedecor and Cochran (1980) by using MSTAT-C Computer Program (Freed et al. 1988).

\subsection{Data recorded}

The following data were recorded:

-Plant height $(\mathrm{cm})$ and the number of branches/plant.

-Herb fresh and dry weights (g/plant)

-Volatile oil percentage in dry herb according to the British Pharmacopeia (1963).

$$
\text { Essential oil \% }=\frac{\begin{array}{c}
\text { Read of } \\
\text { apparatus }
\end{array}}{\begin{array}{c}
\text { Weight of cut } \\
\text { herb }
\end{array}} \times 100
$$

- Volatile oil yield per plant $=$ herb fresh weight per plant $\times$ oil content $\%$.

- Volatile oil yield per feddan $=$ oil yield per plant $\times$ No. of plants per feddan (24000 plants).

- Volatile oil components: Samples taken from the oil obtained in the second cut of the first season for irrigation treatment at $25 \%$ and $75 \%$ ASMD were analysed using gas liquid chromatography (GLC), to determine their main constituents. The use of GLC in the quantitative determinations was performed using the methods described by Bunzen et al. (1969) and Hoftman (1967).

\subsection{Vegetative growth \\ 3.1.1. Plant height and the number of branches/plant}

Data in Table (1) indicate that the irrigation treatments (ASMD), bioantitranspirants: active dry yeast (ADY) and chemical antitranspirants: sodium salicylate (S.S.) and magnesium carbonate $\left(\mathrm{MgCO}_{3}\right)$ had a highly significant effect on both plant height and the number of branches/plant in both seasons.

The tallest plants in the first and second seasons in the two cuts were recorded when the plants were irrigated at 25\% ASMD giving 43.83 and $42.06 \mathrm{~cm}$ at first and second cuts, respectively. The same trend was observed at the second season giving 47.03 and $45.53 \mathrm{~cm}$. The shortest plants in the two cuts of the first season were the plants irrigated at $75 \%$ ASMD as shown in Table (1).

The same trend was observed in the case of number of branches: the greatest number of branches was recorded when the plants were irrigated at 25\% ASMD giving 37.75 and 43.43 at first and second cut of the first season, respectively. While at the second season, the recorded values were 43.64 and 46.86 at first and second cuts, respectively.

The application of antitranspirants also had a significant effect on the plant height and the number of branches of marjoram plants. In the first season, the tallest plants were those sprayed 
Table (a):Mechanical and chemical analyses of the used soil.

\begin{tabular}{|c|c|c|c|c|c|c|c|c|c|}
\hline \multicolumn{10}{|c|}{ Mechanical analysis of the soil } \\
\hline \multicolumn{10}{|c|}{ Particle size distribution (\%) } \\
\hline Soil type & \multicolumn{2}{|c|}{ Coarse sand } & \multicolumn{3}{|c|}{ Fine sand } & \multicolumn{2}{|c|}{ Silt } & \multicolumn{2}{|c|}{ clay } \\
\hline Sandy clay loam & \multicolumn{2}{|c|}{7.33} & \multicolumn{3}{|c|}{50.17} & \multicolumn{2}{|c|}{21.81} & \multicolumn{2}{|c|}{20.67} \\
\hline \multicolumn{10}{|c|}{ Chemical analysis of the soil } \\
\hline \multirow{2}{*}{ Soil type } & \multirow{2}{*}{$\mathbf{p H}$} & \multirow{2}{*}{$\begin{array}{c}\text { E.C. } \\
(\mathbf{d s} / \mathbf{m})\end{array}$} & \multicolumn{4}{|c|}{ Cations (meq/L) } & \multicolumn{3}{|c|}{ Anions (meq/L) } \\
\hline & & & $\mathrm{Ca}^{++}$ & $\mathbf{M g}^{++}$ & $\mathrm{Na}^{+}$ & $\mathbf{K}^{+}$ & $\mathrm{HCO}_{3}^{-}$ & $\mathrm{Cl}^{-}$ & $\mathrm{SO}_{4}$ \\
\hline Sandy clay loam & 7.56 & 1.40 & 6.50 & 3.30 & 4.00 & 1.04 & 3.00 & 5.50 & 6.34 \\
\hline
\end{tabular}

Table (b): Chemical analysis of irrigation water used in the experiment (Lab.Soils Science Department).

\begin{tabular}{|c|c|c|c|c|c|c|c|c|}
\hline \multirow{2}{*}{$\mathbf{p H}$} & \multirow{2}{*}{$\begin{array}{c}\text { E.c. } \\
\mathbf{( d s / m )}\end{array}$} & \multicolumn{3}{|c|}{ Cations (mg/L) } & \multicolumn{3}{c|}{ Anions (mg/L) } \\
\cline { 3 - 8 } & $\mathbf{C a}^{++}$ & $\mathbf{M g}^{++}$ & $\mathbf{N a}^{+}$ & $\mathbf{K}^{+}$ & $\mathbf{H C O}_{3}^{-}$ & $\mathbf{C l}^{-}$ & $\mathbf{S O}_{4}^{-{ }^{-}}$ \\
\hline 7.12 & 0.75 & 2.20 & 1.40 & 3.30 & 0.60 & 0.80 & 3.60 & 3.10 \\
\hline
\end{tabular}

with $\mathrm{ADY}$ at $6 \mathrm{~g} / \mathrm{l}$ giving 50.58 and $47.83 \mathrm{~cm}$ at the first and the second cuts, respectively, while in the second season the recorded data were 50.98 and 51.44 at first and second cuts, respectively.

The shortest plants were the plants sprayed with chemical antitranspirants especially $\mathrm{MgCO}_{3}$ at the rates of 15 or $30 \mathrm{ppm}$ in the first season giving 35.04 and 29.79 at the first and the second cuts, while in the second season the values were 36.59 at the first cut when the plants were treated with $\mathrm{MgCO}_{3}$ at the rates of $15 \mathrm{ppm}$. While at second cut the values were 36.39 when the plants sprayed with $\mathrm{MgCO}_{3}$ at rates of $30 \mathrm{ppm}$.

As for the effect of antitranspirants on number of branches, the recorded data at first season showed that the highest values were obtained when marjoram plants were sprayed with ADY at rate of $8 \mathrm{~g} / \mathrm{l}$ giving 39.28 and 47.78 branches/plant at the first and second cuts, respectively at first season, and 44.39 and 48.40 at second season at first and second cuts respectively.

The lowest values were recorded when the plants were sprayed with chemical antitranspirants $\left(\mathrm{MgCO}_{3}\right)$ at rate of $30 \mathrm{ppm}$ in the two cuts in both seasons. The results are in harmony with the results obtained by Ahmed et al. (2001), Abd ElLatif (2006) and Ali (2009).

Regarding the interaction between the irrigation (ASMD) and antitranspirant treatments on plant height and the number of branches, the data in Table (1) show that in the first season, the tallest plants were 53.31 and 51.84 at the first and the second cuts when sprayed with ADY at 6 or 8 $\mathrm{g} / \mathrm{l}$ and irrigated at 25\% ASMD. Whereas the shortest plants were those irrigated at $75 \%$ ASMD and sprayed with chemical antitranspirants $\left(\mathrm{MgCO}_{3}\right.$ at rate of $\left.30 \mathrm{ppm}\right)$. The values were 29.86 and $26.56 \mathrm{~cm}$ at the first and the second cuts, respectively. At the second season the same trend was recorded with the exception that in the second season the shortest plant in the first cut was recorded in the treatment of $75 \%$ ASMD, recorded 31.78 when the plants sprayed with $\mathrm{MgCO}_{3}$. Regarding the interaction in the case of the number of branches at the first season. The highest values 43.25 and 57.00 branches/plant at first and second cuts, respectively were reported when the plants were irrigated at 25\% ASMD and sprayed with ADY 8g/l, while the lowest values $20.28,26.33$ and 28.33 and 27.33 at first and second cuts in the first and second seasons respectively, were recorded when the plants were irrigated at $75 \%$ ASMD combined with $\mathrm{MgCO}_{3}$ at rates of $30 \mathrm{ppm}$. These results were in accordance to Ahmed et al. (2001) on ambrosia, Abd El-Latif (2006) on sage and Ali (2009) on fennel plants.

\subsubsection{Herb fresh and dry weights}


Table (1): Effect of irrigation and antitranspirant treatments on plant height (cm) and the number of branches of marjoram plants during $2005 / 2006$ and 2006/2007 seasons.

\begin{tabular}{|c|c|c|c|c|c|c|c|c|c|c|c|c|c|c|c|c|}
\hline \multicolumn{17}{|c|}{ Plant height $(\mathrm{cm})$} \\
\hline \multicolumn{9}{|c|}{$1^{\text {st }}$ season } & \multicolumn{8}{|c|}{$2^{n d}$ season } \\
\hline \multirow[t]{2}{*}{ Irrigation } & \multicolumn{4}{|c|}{$\mathbf{1}^{\mathrm{st}}$ cut } & \multicolumn{4}{|c|}{$2^{\text {nd }}$ cut } & \multicolumn{4}{|c|}{$1^{s t}$ cut } & \multicolumn{4}{|c|}{$2^{\text {nd }}$ cut } \\
\hline & $\mathbf{I}_{1}$ & $\mathbf{I}_{2}$ & $\mathbf{I}_{3}$ & Mean & $I_{1}$ & $\mathbf{I}_{2}$ & $\mathbf{I}_{3}$ & Mean & $\mathbf{I}_{1}$ & $\mathbf{I}_{2}$ & $\mathbf{I}_{3}$ & Mean & $\mathbf{I}_{1}$ & $\mathbf{I}_{2}$ & $\mathbf{I}_{3}$ & Mean \\
\hline Control & 41.80 & 41.28 & 36.68 & 39.92 & 42.88 & 39.56 & 35.25 & 39.23 & 46.05 & 43.77 & 40.26 & 43.36 & 44.67 & 41.23 & 35.86 & 40.59 \\
\hline ADY 6 g/L & 53.31 & 52.12 & 46.31 & 50.58 & 50.95 & 47.44 & 45.10 & 47.83 & 56.14 & 51.12 & 45.67 & 50.98 & 55.02 & 52.15 & 47.15 & 51.44 \\
\hline ADY $8 \mathrm{~g} / \mathrm{L}$ & 52.45 & 49.31 & 45.14 & 48.97 & 51.84 & 45.17 & 41.81 & 46.27 & 53.19 & 49.54 & 41.11 & 47.95 & 53.31 & 50.81 & 43.50 & 49.21 \\
\hline S.S 10 ppm & 41.93 & 38.95 & 35.11 & 38.66 & 39.56 & 39.18 & 36.47 & 38.40 & 45.38 & 40.26 & 37.90 & 41.18 & 43.13 & 40.24 & 37.48 & 40.28 \\
\hline S.S 20 ppm & 40.61 & 37.96 & 33.56 & 37.38 & 39.96 & 36.24 & 33.68 & 36.63 & 43.29 & 36.81 & 33.49 & $\mathbf{3 7 . 8 6}$ & 41.38 & 37.87 & 35.90 & 38.38 \\
\hline $\mathrm{MgCO}_{3} 15$ ppm & 37.76 & 36.09 & 33.09 & 35.65 & 35.75 & 31.88 & 28.06 & 31.90 & 41.54 & 36.44 & 31.78 & 36.59 & 40.19 & 37.38 & 33.81 & 37.13 \\
\hline $\mathrm{MgCO}_{3} 30 \mathrm{ppm}$ & 38.95 & 36.32 & 29.86 & 35.04 & 33.45 & 29.37 & 26.56 & 29.79 & 43.62 & 40.21 & 35.91 & 39.91 & 40.99 & 35.25 & 32.93 & 36.39 \\
\hline Mean & 43.83 & 41.72 & 37.11 & & 42.06 & 38.41 & 35.28 & & 47.03 & 42.59 & 38.02 & & 45.53 & 42.13 & 38.09 & \\
\hline LSD at 5\% Irrigation & 0.380 & & & & 0.380 & & & & 0.360 & & & & 0.510 & & & \\
\hline LSD at 5\% AT's & 0.670 & & & & 0.390 & & & & 0.440 & & & & 0.300 & & & \\
\hline LSD at 5\% Interaction. & 1.160 & & & & 0.670 & & & & 0.760 & & & & 0.520 & & & \\
\hline \multicolumn{17}{|c|}{ Number of branches } \\
\hline Control & 34.00 & 30.00 & 24.17 & 29.39 & 36.50 & 30.33 & 23.83 & 30.22 & 38.92 & 34.75 & 24.58 & 32.75 & 44.33 & 40.00 & 29.08 & $\mathbf{3 7 . 8 0}$ \\
\hline ADY 6 g/L & 41.25 & 38.42 & 32.33 & 37.33 & 50.83 & 44.58 & 39.17 & 44.86 & 45.42 & 39.58 & 34.33 & 39.78 & 51.17 & 43.83 & 35.50 & 43.50 \\
\hline ADY $8 \mathrm{~g} / \mathrm{L}$ & 43.25 & 40.17 & 34.42 & 39.28 & 57.00 & 45.33 & 41.00 & 47.78 & 53.08 & 44.58 & 35.50 & 44.39 & 54.75 & 48.00 & 42.45 & 48.40 \\
\hline S.S 10 ppm & 37.75 & 33.33 & 30.17 & 33.75 & 40.33 & 34.25 & 28.00 & 34.19 & 40.58 & 35.33 & 31.58 & 35.83 & 46.83 & 41.00 & 33.08 & 40.30 \\
\hline S.S 20 ppm & 40.25 & 31.42 & 25.17 & 32.28 & 43.33 & 34.83 & 29.00 & 35.72 & 48.67 & 42.33 & 35.00 & 42.00 & 51.58 & 44.17 & 39.67 & 45.14 \\
\hline $\mathrm{MgCO}_{3} 15$ ppm & 36.58 & 31.08 & 24.67 & 30.78 & 39.67 & 32.42 & 27.08 & 33.06 & 41.25 & 35.33 & 28.42 & 35.00 & 42.42 & 36.83 & 31.42 & 36.89 \\
\hline $\mathrm{MgCO}_{3} 30 \mathrm{ppm}$ & 31.17 & 25.08 & 20.58 & 25.61 & 36.33 & 25.67 & 26.33 & 29.44 & 37.58 & 33.42 & 28.33 & 33.11 & 36.92 & 31.58 & 27.33 & 31.94 \\
\hline Mean & $\mathbf{3 7 . 7 5}$ & 32.79 & 27.36 & & 43.43 & 35.34 & 30.63 & & 43.64 & 37.90 & 31.11 & & 46.86 & 40.77 & 34.08 & \\
\hline LSD at 5\% Irrigation & $\mathbf{0 . 3 5 0}$ & & & & 0.370 & & & & 0.490 & & & & 0.380 & & & \\
\hline LSD at $5 \%$ AT's & $\mathbf{0 . 5 5 0}$ & & & & 0.560 & & & & 0.510 & & & & 0.500 & & & \\
\hline LSD at 5\% Interaction. & 0.960 & & & & 0.960 & & & & 0.880 & & & & 0.870 & & & \\
\hline
\end{tabular}

$I_{1}=$ available soil moisture depletion at $25 \%$

$I_{2}=$ available soil moisture depletion at $50 \%$

$I_{3}=$ available soil moisture depletion at $75 \%$
AT's = Antitranspirants

ADY = Active dry yeast

S.S = Sodium Salicylate

$\mathrm{MgCO}_{3}=$ Magnesium carbonate 
Table (2) Effect of irrigation and antitranspirant treatments on herb fresh and dry weights /plant (g.) of marjoram plant during 2005/2006 and 2006/2007 seasons.

\begin{tabular}{|c|c|c|c|c|c|c|c|c|c|c|c|c|c|c|c|c|}
\hline \multicolumn{17}{|c|}{ Herb fresh weight/plant (g) } \\
\hline \multicolumn{9}{|c|}{$\mathbf{1}^{\text {st }}$ season } & \multicolumn{8}{|c|}{$2^{\text {nd }}$ season } \\
\hline \multirow{2}{*}{ Irrigation } & \multicolumn{4}{|c|}{$1^{s t}$ cut } & \multicolumn{4}{|c|}{$2^{\text {nd }}$ cut } & \multicolumn{4}{|c|}{$1^{\text {st }}$ cut } & \multicolumn{4}{|c|}{$2^{\text {nd }}$ cut } \\
\hline & $\mathbf{I}_{1}$ & $\mathbf{I}_{2}$ & $\mathbf{I}_{3}$ & Mean & $\mathbf{I}_{1}$ & $\mathbf{I}_{2}$ & $\mathbf{I}_{3}$ & Mean & $\mathbf{I}_{1}$ & $\mathbf{I}_{2}$ & $\mathbf{I}_{3}$ & Mean & $\mathbf{I}_{1}$ & $\mathbf{I}_{2}$ & $\mathbf{I}_{3}$ & Mean \\
\hline Control & 46.79 & 38.57 & 32.57 & 39.31 & 69.49 & 59.82 & 35.36 & 54.89 & 52.25 & 45.21 & 35.16 & 44.21 & 73.41 & 63.62 & 50.98 & 62.67 \\
\hline ADY $6 \mathrm{~g} / \mathrm{L}$ & 71.55 & 61.91 & 39.59 & 57.68 & 90.13 & 80.58 & 60.25 & 76.99 & 78.45 & 70.00 & 55.79 & 68.08 & 99.63 & 84.46 & 68.15 & 84.08 \\
\hline ADY $8 \mathrm{~g} / \mathrm{L}$ & 74.25 & 64.47 & 56.56 & 65.09 & 95.22 & 83.64 & 62.86 & 80.57 & 71.42 & 67.21 & 48.76 & 62.46 & 103.20 & 92.07 & 79.01 & 91.43 \\
\hline S.S 10 ppm & 52.68 & 48.72 & 36.37 & 45.92 & 69.00 & 65.71 & 55.72 & 63.48 & 56.50 & 50.21 & 42.50 & 49.74 & 76.60 & 69.02 & 53.84 & 66.49 \\
\hline S.S 20 ppm & 49.28 & 39.36 & 28.94 & 39.19 & 61.70 & 54.16 & 43.89 & 53.25 & 53.67 & 43.33 & 35.35 & 44.12 & 69.30 & 59.53 & 49.97 & 59.60 \\
\hline $\mathrm{MgCO}_{3} 15 \mathrm{ppm}$ & 50.14 & 40.12 & 32.20 & 40.82 & 61.67 & 51.71 & 42.49 & 51.96 & 55.32 & 45.26 & 34.24 & 44.94 & 74.13 & 65.80 & 53.87 & 64.60 \\
\hline $\mathrm{MgCO}_{3} 30 \mathrm{ppm}$ & 48.25 & 40.89 & 28.92 & 39.35 & 54.43 & 50.81 & 39.66 & 48.30 & 51.77 & 42.32 & 31.74 & 41.94 & 67.38 & 61.08 & 48.52 & 58.99 \\
\hline Mean & 56.13 & 47.72 & 36.45 & & 71.66 & 63.78 & 48.60 & & 59.91 & 51.93 & 40.51 & & 80.52 & 70.80 & 57.76 & \\
\hline LSD at $5 \%$ Irrigation & 0.300 & & & & 0.880 & & & & 0.230 & & & & 0.230 & & & \\
\hline LSD at 5\% AT's & 0.430 & & & & 0.670 & & & & 0.320 & & & & 0.380 & & & \\
\hline LSD at $5 \%$ Interaction. & 0.740 & & & & 1.160 & & & & 0.550 & & & & 0.650 & & & \\
\hline \multicolumn{17}{|c|}{ Herb dry weight/plant (g) } \\
\hline Control & 17.79 & 14.79 & 12.61 & 15.06 & 27.63 & 26.98 & 14.16 & 22.92 & 18.03 & 15.59 & 13.31 & 15.64 & 28.12 & 25.19 & 20.09 & 24.47 \\
\hline ADY $6 \mathrm{~g} / \mathrm{L}$ & 28.34 & 20.31 & 14.28 & 20.98 & 37.45 & 30.67 & 23.63 & 30.58 & 28.44 & 26.24 & 21.07 & 25.25 & 38.65 & 34.13 & 25.37 & 32.72 \\
\hline ADY $8 \mathrm{~g} / \mathrm{L}$ & 28.63 & 22.52 & 19.36 & 23.50 & 36.98 & 33.84 & 23.91 & 31.58 & 26.38 & 23.15 & 17.08 & 22.20 & 37.90 & 32.00 & 26.93 & 32.28 \\
\hline S.S 10 ppm & 22.86 & 18.90 & 13.91 & 18.56 & 27.68 & 24.39 & 21.99 & 24.69 & 21.00 & 17.56 & 14.79 & 17.78 & 29.66 & 25.29 & 19.29 & 24.75 \\
\hline S.S 20 ppm & 19.01 & 14.96 & 10.16 & 14.71 & 26.95 & 21.91 & 18.91 & 22.59 & 19.30 & 15.55 & 13.85 & 16.23 & 25.59 & 21.93 & 18.02 & 21.85 \\
\hline $\mathrm{MgCO}_{3} 15 \mathrm{ppm}$ & 20.44 & 15.46 & 11.36 & 15.75 & 27.26 & 26.88 & 19.24 & 24.46 & 20.49 & 15.90 & 13.82 & 16.74 & 29.46 & 25.06 & 21.32 & 25.28 \\
\hline $\mathrm{MgCO}_{3} 30$ ppm & 19.95 & 14.39 & 9.69 & 14.68 & 23.48 & 20.84 & 18.52 & 20.95 & 19.12 & 15.65 & 12.53 & 15.77 & 26.21 & 23.64 & 19.44 & 23.10 \\
\hline Mean & 22.43 & $\mathbf{1 7 . 3 3}$ & 13.05 & & 29.63 & 26.50 & 20.05 & & 21.82 & 18.52 & 15.21 & & 30.80 & 26.75 & 21.49 & \\
\hline LSD at $5 \%$ Irrigation & 0.200 & & & & 0.300 & & & & 0.170 & & & & 0.100 & & & \\
\hline LSD at 5\% AT's & 0.350 & & & & 0.310 & & & & 0.230 & & & & 0.210 & & & \\
\hline LSD at $5 \%$ Interaction. & 0.610 & & & & 0.540 & & & & 0.390 & & & & 0.360 & & & \\
\hline
\end{tabular}

$I_{1}=$ available soil moisture depletion at $25 \%$

$\mathbf{I}_{2}=$ available soil moisture depletion at $\mathbf{5 0 \%}$

$I_{3}=$ available soil moisture depletion at $75 \%$
AT's = Antitranspirant

ADY= Active dry yeast

S.S = Sodium Salicylate

$\mathrm{MgCO}_{3}=$ Magnesium carbonate 
Data in Table (2) indicate that increasing the rates of ASMD from $25 \%$ up to $75 \%$ resulted in significant decreases in fresh and dry weights in both cuts in the two seasons. The highest fresh and dry weights/plant were recorded when marjoram plants were irrigated at 25\% ASMD. These results are in harmony with El-Gamassy et al., (1977) and El-Khateeb and Bosellah (1991) on periwinkle plants.

As for the effect of antitranspirants on the fresh and dry weights of marjoram plants, it is clear that bioantitranspirants (ADY) were effective in this concern than the chemical antitranspirants (S.S. and $\mathrm{MgCO}_{3}$ ). The highest values were recorded when marjoram plants were sprayed with ADY at the rates of $8 \mathrm{~g} / \mathrm{l}$ giving $65.09 \mathrm{~g}$ and $80.57 \mathrm{~g}$ fresh weight and 23.50 and $31.58 \mathrm{~g}$ dry weight/plant in the first and the second seasons, respectively. The same trend was observed in the second cut of the second season, while in the first cut the highest values $(68.08 \mathrm{~g}$ fresh weight and $21.07 \mathrm{~g}$ dry weight) were obtained from plants sprayed with ADY at $6 \mathrm{~g} / \mathrm{l}$. These results are in harmony with Ahmed (1998) on marjoram plants, Ahmed et al., (2001) on Ambrosia maritima, Hussain (2002) on Majorana hortensis and Ali (2009) on fennel plants.

Lowest fresh and dry weights were obtained when the plants were treated with chemical antitranspirants in most cases in the two cuts in the two seasons especially when the plants were treated with $\mathrm{MgCO}_{3}$.

Concerning the interaction effects between ASMD and antitranspirants the data show that the highest values(74.25 and $95.22 \mathrm{~g} / \mathrm{plant})$ fresh weight and 28.63 and $37.45 \mathrm{~g} / \mathrm{plant}$ dry weight/plant were recorded when the plants were irrigated at 25\% ASMD and sprayed with ADY at 6 or $8 \mathrm{~g} / \mathrm{l}$. The same trend was observed at the second season.

The increment in herb weight may be due to the effective role of both irrigation at best ASMD and ADY application in increasing plant height and the number of branches which affect increasing herb weight. Beside the increasing photosynthesis consequently more metabolic activities were obtained and led to an increment in plant growth.

The Lowest values were obtained when the plants were sprayed with chemical antitranspirants $\left(\mathrm{MgCO}_{3}\right.$ at $30 \mathrm{ppm}$ in most cases). Similar reduction in the dry weight of some field crops was recorded by Abu-Grab et al.,(1994) They recorded that, chemical antitranspirants caused a reduction in the dry matter. These materials form film affecting stomata which affect photosynthesis which was reflected on net dry mater.

\subsection{Volatile oil characteristics: 3.2.1. Volatile oil percentage:}

Data presented in Table (3) show that the effect of irrigation (ASMD) and its interaction with antitranspirants had a significant effect on volatile oil \% of dry herb of marjoram plants. Increasing ASMD from 25\% up to $75 \%$ led to a slight increase in volatile oil percentage especially at 50\% ASMD, while the highest value $1.37 \%$ at first cut obtained when plants were irrigated at 50\% ASMD while recorded value at second cut $(1.40 \%)$ when the plants were irrigated at $75 \%$ ASMD in first season, in second season the highest value $(1.37 \%)$ was obtained when the plants irrigated at $75 \%$ ASMD at first cut in the second season. While at second cut the values were $1.26 \%$ when the plants were irrigated with $25 \%$ ASMD. These results are in accordance to Afify et al.,(1993). These results may be explained through the findings of Penka (1978) who mentioned that essential oil is the product of the respiratory catabolic processes which increased when the plants grow under the dry conditions.

As for the effects of antitranspirants it is clear that all treatments decreased volatile oil \% except the plants treated with $\mathrm{MgCO}_{3}$ at $30 \mathrm{ppm}$ at two cuts in the first season, the highest values 1.57 and $1.54 \%$ combined with irrigation at $50 \%$ or $75 \%$ ASMD at first and second cuts respectively. While the second season, highest values 1.54 and $1.39 \%$ when the plants sprayed with S.S. at 10 or $20 \mathrm{ppm}$ combined with $75 \%$ or $25 \%$ ASMD at first and second cuts, respectively.

These chemical antitranspirants reduced transpiration and increased water leaf content which reflect in increasing photosynthesis. These results are in harmony with El-Bably and Awad (2007), Bishr (1972) and Khater et al. (1996).

\subsubsection{Volatile oil components}

Samples of marjoram essential oil subjected to G.C. analysis were taken from the plants of second cut in first season grown under $25 \%$ ASMD and 75\% ASMD. Data in Table (4) indicate that, the main components were terpinene-4-ol, linalyl acetate, $\alpha$-terpineol, linalool and $\beta$-pinene.

Regarding the effect of available soil moisture depletion (ASMD) and antitranspirant treatments on the composition of volatile oil, it could be concluded that, the maximum terpinene-4-ol content was recorded with the treatments of $25 \%$ ASMD and 75\% ASMD were giving 30.09 and $30.78 \%$, respectively when marjorum plants were sprayed with sodium salicelate (S.S.) at $10 \mathrm{ppm}$ and active dry yeast (ADY) respectively. The 
Table (3) Effect of irrigation and antitranspirant treatments on volatile oil percentage in dry herb of marjoram plant during $2005 / 2006$ and 2006/2007 seasons.

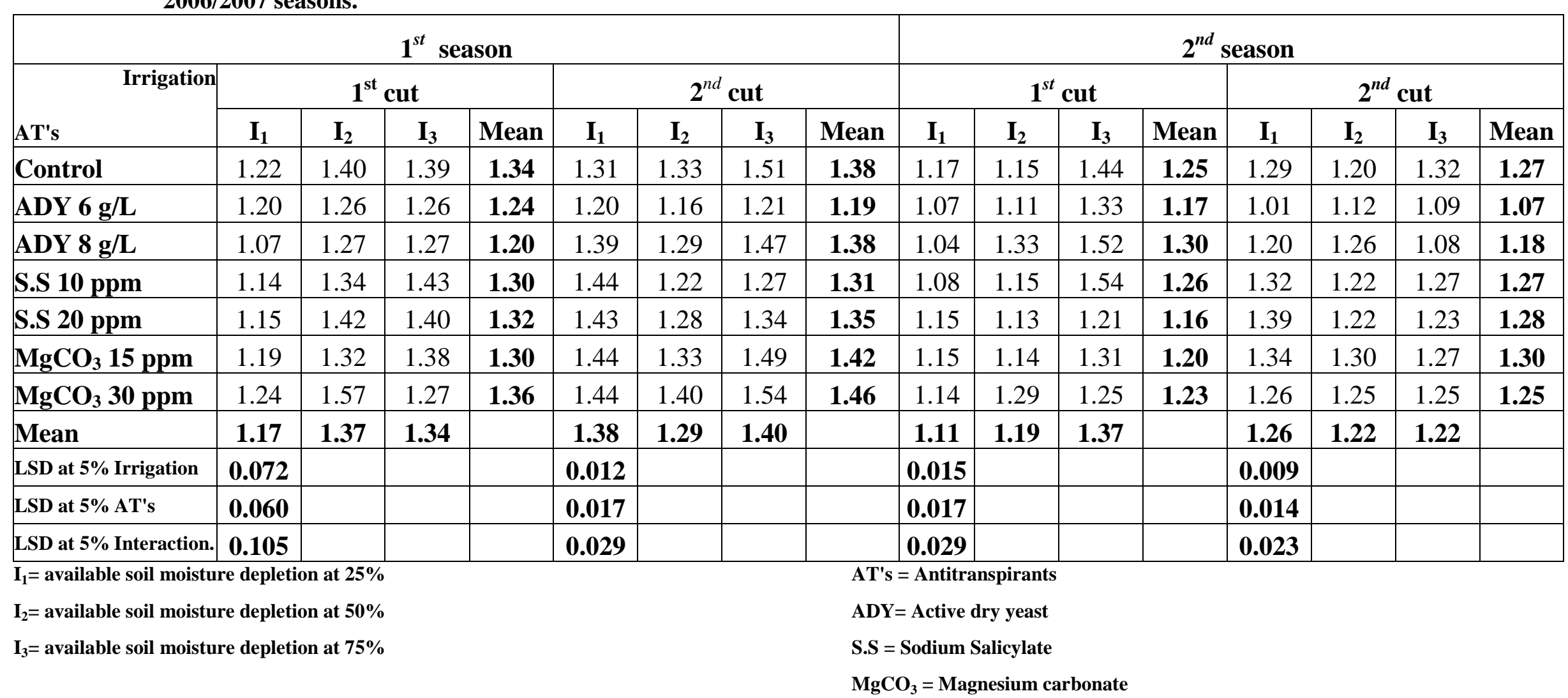


Table (4) Effect of irrigation and antitranspirant treatments on volatile oil components of marjoram plants during first season in the second cut.

\begin{tabular}{|c|c|c|c|c|c|c|c|c|c|c|c|c|c|c|}
\hline \multirow[t]{2}{*}{ Treatments } & \multicolumn{7}{|c|}{$\mathbf{I}_{1}$} & \multicolumn{7}{|c|}{$\mathbf{I}_{3}$} \\
\hline & 导 & 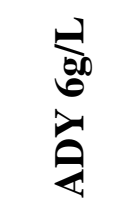 & 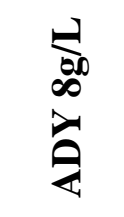 & 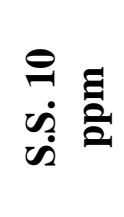 & 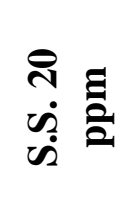 & $\bigcup_{\sum_{\infty}^{\infty}}^{\infty} \equiv$ & 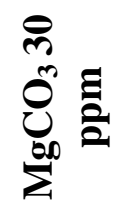 & نे & 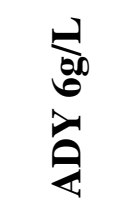 & \begin{tabular}{l}
$\overrightarrow{2}$ \\
$\infty$ \\
\multirow{2}{*}{} \\
2
\end{tabular} & 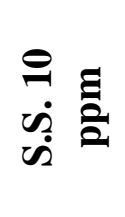 & 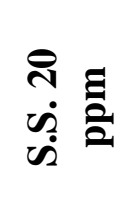 & $\sum_{\sum_{0 \infty}^{\infty}}^{\infty} \equiv$ & $\sum_{\sum_{i}^{\infty}}^{\infty}$ \\
\hline$\alpha$ - Pinene & 0.76 & 1.20 & - & 0.73 & 0.49 & 0.76 & 0.86 & 0.70 & - & 0.81 & 0.85 & 0.83 & - & - \\
\hline B-Pinene & 6.29 & 7.84 & 7.15 & 7.20 & 6.10 & 7.00 & 6.89 & 4.15 & 5.64 & 5.25 & 6.44 & 7.61 & 7.47 & 6.91 \\
\hline Limonene & 2.54 & 3.40 & 3.60 & 5.46 & 3.70 & 3.18 & 2.97 & 3.72 & 2.12 & 2.61 & 2.17 & 3.63 & 3.77 & 3.76 \\
\hline 1,8 Cineole & 3.76 & 4.84 & 5.20 & 3.87 & 4.21 & 4.36 & 5.35 & 3.84 & 3.17 & 4.01 & 3.95 & 4.73 & 4.51 & 3.90 \\
\hline$\gamma$-Terpineol & 4.97 & 4.82 & 5.66 & 6.08 & 5.97 & 3.45 & 5.85 & 1.75 & 1.76 & 1.78 & 4.01 & 3.95 & 3.53 & 3.77 \\
\hline Linolool & 6.72 & 6.4 & 9.71 & 8.08 & 6.60 & 8.82 & 8.38 & 9.45 & 8.29 & 10.21 & 10.86 & 12.60 & 10.17 & 10.06 \\
\hline Terpinene-4-ol & 26.45 & 21.87 & 25.28 & 30.09 & 19.21 & 25.02 & 25.22 & 20.38 & 30.78 & 26.26 & 23.60 & 20.66 & 30.70 & 25.53 \\
\hline$\alpha-$ Terpineol & 9.82 & 5.60 & 9.71 & 6.05 & 6.21 & 6.43 & 8.38 & 9.56 & 8.25 & 10.21 & 10.86 & 12.60 & 10.17 & 10.06 \\
\hline Linalyl acetate & 16.82 & 16.02 & 19.11 & 16.97 & 15.45 & 17.69 & 16.95 & 16.11 & 20.82 & 17.13 & 17.76 & 16.88 & 17.11 & 18.42 \\
\hline Estragol & 1.37 & 1.86 & 1.60 & 1.15 & 1.17 & 2.48 & 1.71 & 4.47 & 0.71 & 0.93 & 0.20 & 1.71 & 1.44 & 1.21 \\
\hline B -Caryophellene & 2.76 & 2.25 & 3.49 & 3.38 & 4.24 & 2.64 & 2.14 & 3.01 & 2.34 & 4.06 & 5.38 & 5.31 & 2.27 & 2.75 \\
\hline Eugenol & 5.16 & 5.50 & 6.86 & 6.66 & 10.90 & 6.79 & 6.20 & 5.28 & 8.26 & 9.13 & 8.38 & 8.62 & 4.92 & 5.79 \\
\hline Sitronillol & 4.37 & 1.40 & 2.01 & 2.42 & 4.21 & 2.67 & 1.40 & 2.23 & 2.71 & 4.70 & 2.03 & - & 2.05 & 1.48 \\
\hline Unknown & 8.21 & 11.13 & 1.62 & 1.92 & 11.54 & 8.71 & 7.7 & 15.26 & 5.15 & 3.70 & 3.05 & 0.87 & 11.89 & 6.36 \\
\hline
\end{tabular}


Table (5) Effect of irrigation and antitranspirant treatments on volatile oil yield per plant (g) and feddan (kg) of marjoram plant during 2005/2006 and 2006/2007 seasons.

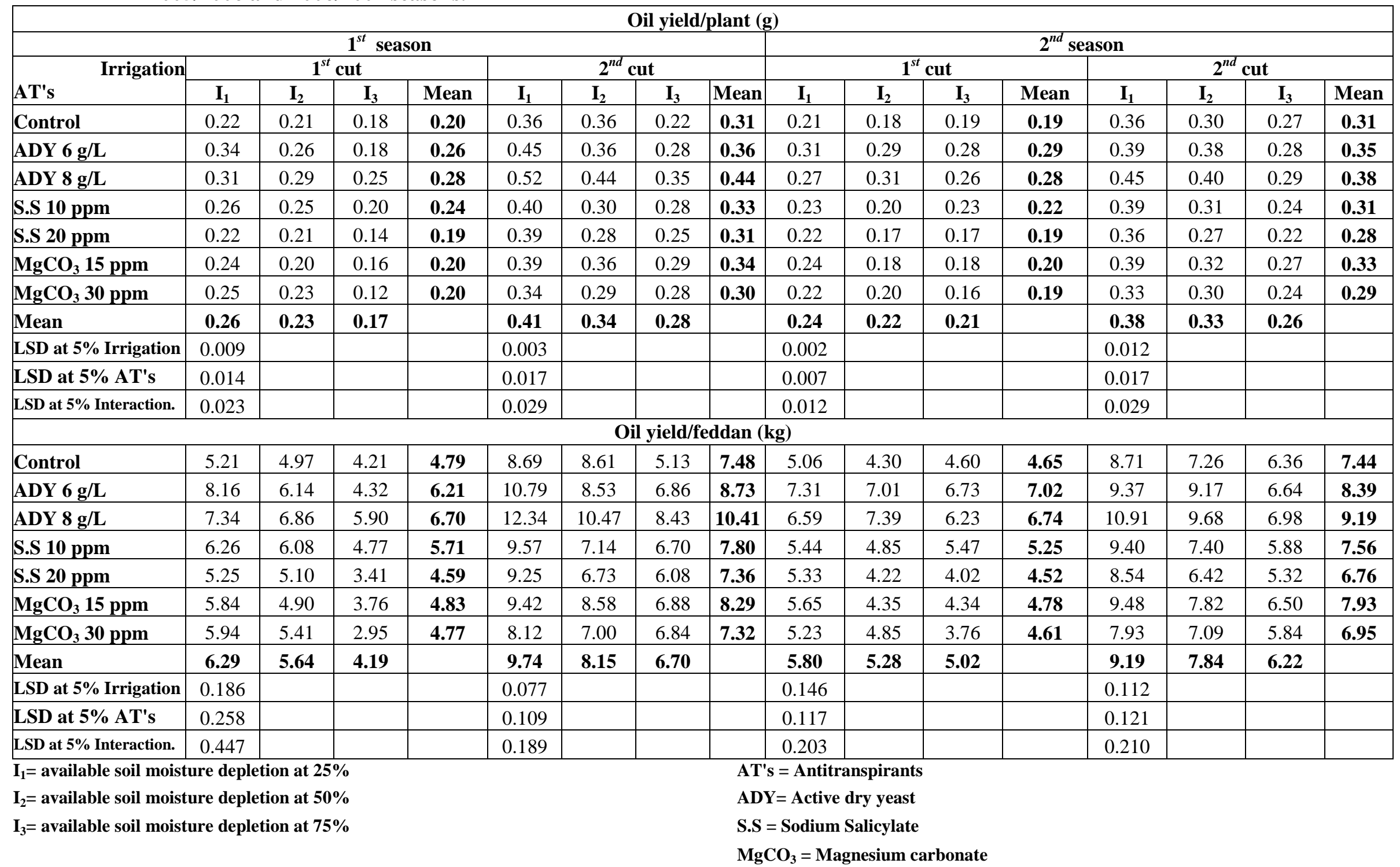


maximum linalyl acetate value (19.11\%) for $25 \%$ ASMD recorded when the plants were sprayed with (ADY) at $8 \mathrm{~g} / \mathrm{l}$, while with the treatment of $75 \%$ ASMD, the maximum value was $20.82 \%$ when the plants were sprayed with ADY at rates of $6 \mathrm{~g} / \mathrm{l}$.

Concerning the effect of irrigation at different available soil moisture depletion (ASMD) and antitranspirants on the content of $\alpha$-terpineol, it could be noticed that 25\% ASMD its content was decreased in all antitranspirant applications. While with $75 \%$ ASMD, slight increment was recorded in most cases in comparison to control. The maximum value $(12.60 \%)$ was recorded when the plants were sprayed with sodium salicylate (S.S.) at $20 \mathrm{ppm}$.

As for linalool content, the recorded data revealed that its content increased in most cases at $25 \%$ and $75 \%$ ASMD combined with antitranspirant treatments, the maximum value $(9.71 \%)$ was recorded when the plants irrigated at $25 \%$ ASMD combined with ADY at 8g/l.

Concerning $\beta$-pinene content, the maximum value $7.84 \%$ was obtained at $25 \%$ ASMD combined with ADY at $6 \mathrm{~g} / \mathrm{l}$, while at $75 \%$ ASMD, the maximum value $(7.61 \%)$ was obtained when the plants were treated with S.S. at $20 \mathrm{ppm}$. All values were found to be within the standard range and are in agreement with those of Rhyu (1979), Hanafy (1989), El-Ghadban (1998), Mahfouz (2003) and Dewidar (2007).

\subsubsection{Volatile oil yield per plant and per feddan}

Data presented in Table (5) show that in all cuts in both seasons, the volatile oil yield/plant and per feddan decreased when ASMD increased from $25 \%$ up to $75 \%$.

The highest volatile oil yield/plant $(0.34$ $\mathrm{g} /$ plant) was obtained when the plants were sprayed with ADY at $6 \mathrm{~g} / \mathrm{l}$ and irrigated with $25 \%$ ASMD in the first cut, while in the second cut values were 0.52 when the plants were sprayed with ADY at $8 \mathrm{~g} / \mathrm{l}$ and irrigated with 25\% ASMD too. The same trend was obtained in the second season, the values were 0.31 and 0.45 in the first and second cuts, respectively. As for volatile oil yield/feddan showed that volatile oil yield/feddan followed a similar trend as on plants values giving 8.16 and $12.34 \mathrm{~kg} /$ feddan in the first season and 7.31 and $10.91 \mathrm{~kg} /$ feddan in the second season in the first and the second cuts, respectively. These results are in harmony with El-Bably and Awad (2007) who reported that the highest oil yield was obtained with the shortest irrigation period. Agena (1966) on Pelargonium graveolens, Bishr (1972) on sweet marjoram and Khater et al. (1996) on Mentha piperita.
From the above results it can be recommended to irrigate marjoram plants at $25 \%$ ASMD and sprayed with ADY as a bio antitranspirants at the rates of 6 or $8 \mathrm{~g} / 1$. to obtain high fresh and dry weight/plant and feddan, also to obtain high volatile oil yield/plant and per feddan irrigated marjoram plants at $25 \%$ and sprayed with $\mathrm{ADY}$ at 6 or $8 \mathrm{~g} / \mathrm{l}$ too.

\section{REFERENCES}

Abd El-Latif Esraa S.M. (2006). Effect of Chemical, Organic Fertilizers and Spraying with Active Dry Yeast on Growth, Oil Production and Plant Constituents of Sage (Salvia officinalis L.)Plant. M.Sc. Thesis, Fac. Agric., Cairo Univ., Egypt.

Abu-Grab O.S., Kooud E.E. and Abdel-Maksoud H.H. (1994). Effect of some chemicals transpiration suppressants on yield, water constituents, chlorophyll and mineral contents for some field crops. Mansoura Univ. J. Agric. Sci., 19(3):875-889.

Afify M. M., Mazrou M. M. and Eraki M. A. (1993). The growth and essential oil content of Salvia officinalis L. plants as affected by watering intervals, nitrogen fertilization and their combinations. Zagazig J. Agric. Res. 20(6): 1913-1924.

Agena E.A.E. (1966). Effect of Some Cultural Treatments on the Growth and Oil Yield of Geranium Plants (Pelargonium gravealens). M.Sc. Thesis, Faculty of Agric., Ain Shams Univ., Egypt.

Ahmed E.T. (1998). Influence of concentration and time of spraying active dry yeast on volatile oil content of marjoram plants. J. Agric. Sci. Mansoura Univ., 23(11):50675081.

Ahmed Sh. K., Ali A.F. and Khater M.R. (2001). Effect of salinity treatments and active dry yeast on growth and active ingredients of Ambrosia maritima L. The $5^{\text {th }}$ Arabian Horticulture Conference. Ismailia Egypt. March 24-28, Egypt.

Ali Hanan M.H. (2009). Effect of Biofertilization on Growth, Yield and Constituents of Fennel Plant. Ph.D. Thesis, Fac. Agric. Cairo Univ., Egypt.

Bishr G.A. (1972). Effect of Irrigation and Spacing Treatments on the Growth and Yield of Majorana hortensis. M.Sc. Thesis, Ain Shams Univ., Egypt.

British Pharmacopeia (1963). Determination of Volatile Oil in Drugs. The Pharmaceutical Press, London.

Bunzen J. N., Guichard J., Labbe P., Sperinnet P. J. and Trenchant J. (1969). Practical Manual 
of Gas Chromatography. J. Trenchant Ed., ElSeiver Publ.Comp., Amsterdam, London.

Chapman H.D. and Pratt P.F. (1961 ). "Methods of Analysis for Soil , Plant and Water". Univ. of California, Division of Agric. Sci., Riverside, USA. 35-67.

Dewidar A.A. (2007). Post-harvest Studies on Some Aromatic Plants. Ph.D. Thesis. Fac. Agric. Kafr El-Sheikh Univ., Egypt.

El-Bably A. Z. and Awad M. M. (2007). Effect of irrigation and nitrogen fertilization on productivity, seed quality, and water use efficiency of canola (Brassica napus L.) in North Delta, Egypt. Alexandria Journal of Agricultural Research,52(3):91-97.

El-Gamassy A. M., Hassan H. A., El-Gendy S. A. and Khalil M. M. (1977). The effect of irrigation on the herb and oil yield of two mint species. Res. Bull. 735, Fac. of Agric, Ain Shams.

El-Ghadban E.A.E. (1998). Effect of some Organic and Inorganic Fertilizers on Growth, Oil Yield and Chemical Composition of Spearmint and Marjoram Plants. Ph.D. Thesis. Fac. Agric. Cairo Univ., Egypt.

El-Khatteb M. A. and Boselah A. A. N. (1991). Effect of irrigation intervals and potassium fertilization on periwinkle. J. Agric. Res. Tanta Univ., 17(1):113-123.

Freed R., Eisensmith S.P., Goetz S., Reicosky D., Smail V.W. and Wolberg P. (1988). Users Guide to MSTAT-C. Michigan State University, East Lansing.

Hanafy M.S. (1989). Effect of Chemical Fertilization and Salinity on Production of Herb and Essential Oil of Marjoram Plants
(Majorana hortensis, Moench). Ph.D. Thesis. Fac. Agric Cairo Univ., Egypt.

Hoftman E. (1967). Chromatography. Reinhold Puble. Corp., $2^{\text {nd }}$ ed. p. 208- 515.

Hussain M.A.M. (2002). Effect of Some Agricultural Treatments on Growth and Chemical Composition of Majorana Hortensis, Moench Plant. M.Sc. Thesis, Fac. Agric., Minia Univ., Egypt.

Khater M.R., Ahmed S.K. and El-Zahawy A.M. (1996). A study on the effect of foliar spray and irrigation intervals on the vegetative growth and oil of Mentha piperita. Egypt. J. Agric. Res., 74(1):135-149.

Mahfouz S.A.S. (2003). Effect of biofertilization on growth and oil production on Majorana hortensis, Moench. Ph. D Thesis, Fac. Agric. Cairo Univ., Egypt.

Nasroui B. (1993). Role of antitranspirant films in protecting plants against fungal diseases. Annales-de-l'Institut-National- de laRecherche-Agronomique- de Tunisie, 66(12):125-135.

Penka M. (1978). Influence of irrigation on the contents of effective substances in official plants. Acta Horticulture Spice and Medicinal plants, 73:181-198.

Rhyu H. (1979). Gas chromatographic characterization of sages of various geographic origins. J. Food Sci., 44(55):1373.

Snedecor G.W. and Cochran W.G. (1980). Statistical Methods. $6^{\text {th }}$ Ed. Iowa State Univ. Press, Iowa, USA.

Yadava R.N. and Khore M.K. (1995). Triterpenoid from Majorana hortensis. Fitoterapia, 66(2):185.

$$
\begin{aligned}
& \text { تأثير معاملات الري و مضادات النتح على نمو و إنتاجية و المكونات الكيميائية لنبات البردقوش } \\
& \text { طارق أبو دهب حمح أبو دهب - إبراهيم محم أحمد هريدي* - بيومي علي بيومي منصور }
\end{aligned}
$$

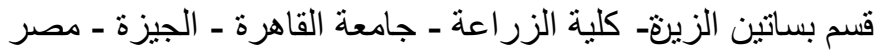

$$
\begin{aligned}
& \text { * قسم بحوث النباتات الطبية و العطرية ، معهد بحوث الزئة البساتين، مركز البحوث الزئة الزراعية ، الجيزة ـ مصر }
\end{aligned}
$$

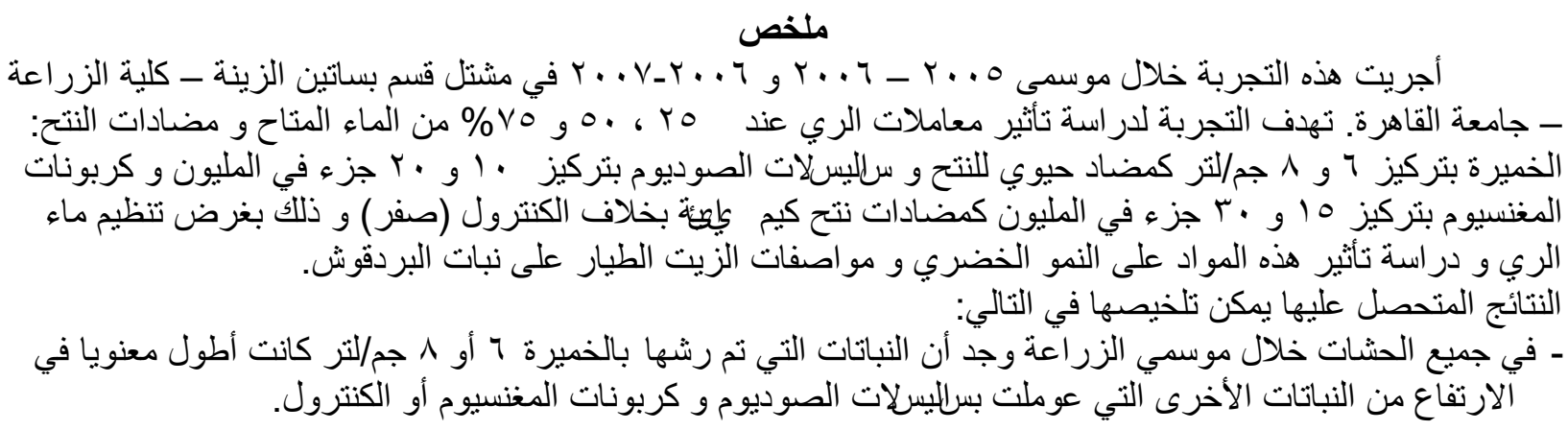




$$
\text { - لوحظ نفس الاتجاه فى تفريع نبات البردقوش. }
$$

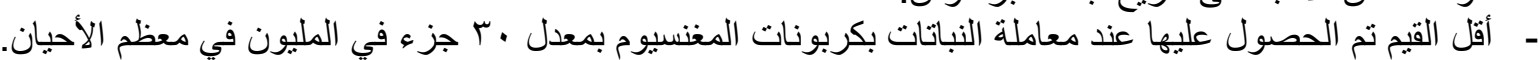

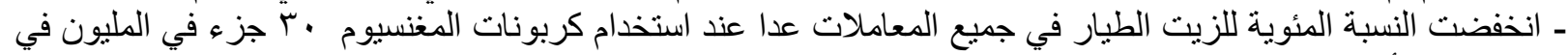

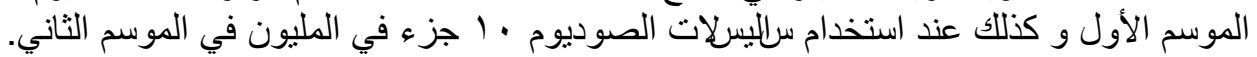

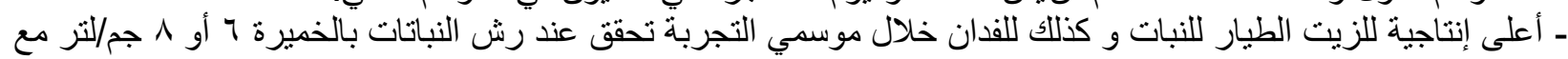

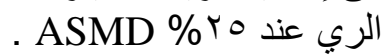

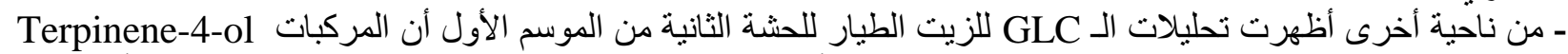

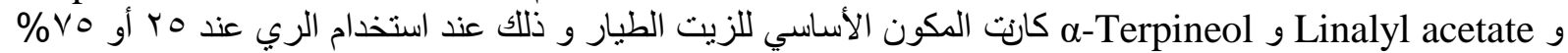

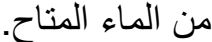

المجلة العلمية لكلية الزراعة - جامعة القاهرة (المجلد61) العدد الثالث (يولية2810-274:205). 